ВІСНИК

ОДЕСЬКОГО НАЦІОНАЛЬНОГО

МОРСЬКОГО УНІВЕРСИТЕТУ

№ 2 (59), 2019
HERALD

OF THE ODESSA NATIONAL

MARITIME UNIVERSITY № 2 (59), 2019

УДК 656.09

DOI 10.33082/2226-1915 -2-2019-155-165

\title{
ПРАКТИКА ПРЕДОСТАВЛЕНИЯ \\ НЕЗАВИСИМЫХ ИНСПЕКЦИОННЫХ УСЛУГ ПРИ ОРГАНИЗАЦИИ КОНТЕЙНЕРНЫХ ПЕРЕВОЗОК ШРОТА ПОДСОЛНЕЧНОГО
}

\author{
T.Е. Корниец \\ к.т.н., доцент, \\ доцент кафедры «Эксплуатация портов и технология грузовых работ» \\ А.К. Смаркалова \\ ассистент кафедры «Эксплуатация портов и технология грузовых работ» \\ Одесский наџиональный морской университет
}

Аннотация. В статье рассматривается практика предоставления независимых инспекиионных услуг. Особое внимание уделено узко специфическим направлениям деятельности сюрвейеров при организации контейнерных перевозок в условиях требований китайского рынка к произведенному в Украине шроту подсолнечному.

Ключевые слова: сюрвей, сюрвейер, независимое инспектирование, контейнерные перевозки, шрот подсолнечный.

УдК 656.09

DOI 10.33082/2226-1915 -2-2019-155-165

\section{ПРАКТИКА НАДАННЯ \\ НЕЗАЛЕЖНИХ ІНСПЕКЦЙНИХ ПОСЛУГ ПРИ ОРГАНІЗАЦЇ̈ КОНТЕЙНЕРНИХ ПЕРЕВЕЗЕНЬ ШРОТУ СОНЯШНИКОВОГО}

\author{
Т.Є. Корнієць \\ к.т.н., доцент,
}

доцент кафедри «Експлуатація портів і технологія вантажних робіт»

А.К. Смаркалова

асистент кафедри «Експлуатація портів і технологія вантажних робіт»

Одеський наиіональний морський університет

Анотація. В даній статі розглянута практика надання незалежних інспекиійних послуг. Особлива увага приділена вузько специфічним напрямкам діяльності сюрвейєрів при організаиії контейнерних перевезень в умовах вимог китайського ринку до виробленого в Украӥні шрота соняшникового.

Ключові слова: сюрвей, сюрвейєр, незалежне інспектування, контейнерні перевезення, шрот соняшниковий.

(С Корниец Т.Е., Смаркалова А.К., 2019 


\title{
UDC 656.09
}

DOI 10.33082/2226-1915 -2-2019-155-165

\section{PRACTICE OF PROVIDING INDEPENDENT INSPECTION SERVICES IN PROCESS OF ORGANISATION OF SUNFLOWERSEED MEAL TRANSPORTATIONS IN CONTAINERS}

\author{
T.E. Korniets \\ $\mathrm{PhD}$, associate professor \\ associate professor «Department of Port Operation and Cargo Handling Technology» \\ A.K. Smarkalova \\ assistant «Department of Port Operation and Cargo Handling Technology»

\section{Odessa National Maritime University}

Abstract. This article reviews the practice of providing independent inspection services. Particular focusis placedon the narrowly specific areas of surveyors' functions in container transportations organization upon conditions of the Chinese market requirements for sunflower meal produced in Ukraine.

Keywords: survey, independent inspections, transportation in containers, sunflower seed meal.

Введение. История независимой инспекционной - сюрвейерской деятельности насчитывает десятки лет, и на сегодняшний день представляют собою незаменимую, в международной практике, сферу услуг. Данный вид услуг востребован в международной торговле, а также в большинстве отраслей материального производства, основным из которых можно выделить транспорт, а для Украины, как для морского государ-ства, именно морской транспорт.

Потребность в инспекционных услугах может возникнуть на всех этапах транспортного процесса, так как основным интересом всех его участников - судовладельцев, фрахтователей, стивидоров, грузовладельцев и грузополучателей, страховых агентов и экспедиторов является минимизация всевозможных потерь. Любая из сторон может привлечь к работе в своих интересах одного или нескольких независимых инспекторов.

Особенно важную роль работа независимого сюрвейера играет в странах ЕС и США, поскольку, при соблюдении инспектором основного принципа независимости, он остаётся незаинтересованной стороной в любом транспортном процессе, оставаясь его полноправным участником. С приобретением Украиной независимости, данный вид деятельности стал прогрессивно развиваться как неотъемлемое звено системы рыночных отношений и в нашем государстве. 
ВІСНИК

ОДЕСЬКОГО НАЦІОНАЛЬНОГО

МОРСЬКОГО УНІВЕРСИТЕТУ № 2 (59), 2019
HERALD

OF THE ODESSA NATIONAL

MARITIME UNIVERSITY № 2 (59), 2019

Постановка проблемы и ее связь с научными и практическими заданиями. В конце XX века Украина широко экспортировала семена подсолнечника, в то время как отгрузки подсолнечного масла, а также образующегося после его экстракции, шрота, производились эпизодически. После того, как в 1999 году в Украине был подписан закон о введении $23 \%$ пошлины на экспорт семян подсолнечника для качественного регулирования рынка, вывоз «семечки» стал экономически не выгоден. Благодаря этому масложировая отрасль начала стремительно развиваться, а в строительство экстракционных заводов и перевалочных терминалов начали активно вкладывать средства. Помимо одного, уже существовавшего, Ильичевского масляного терминала были построены заводы компаниями «Олсидс Блек Си», «Дельта Вилмар СНГ», Агрохол-дингом «КернелГруп», «Рисоил», «Сантрейд»- украинский филиал международной организации Bunge, и другие, которые занимаются производством и продажей масел, а также, побочных продуктов его переработки - шрота и жмыха.

В период с 2017 по 2018 гг., существенно выросла доля экспорта именно шрота подсолнечного произведенного в Украине, объемы которого составили 4,2 млн. т. [1]. Основными рынками его сбыта, на сегодняшний день, являются Малайзия, Индия и страны Средней Азии, а также после подписания с Украиной в сентябре 2017 года протокола санитарных и фитосанитарных требований, в топ-импортеров украинского подсолнечного шрота стала входить Китайская Народная Республика.

Специфические требования КНР к качеству шрота подсолнечного произведенного в Украине повлекли за собой формирование определенной практики предоставления независимых инспекционных услуг, что и обусловило актуальность данной статьи.

Анализ исследований и публикаций. Изучением структуры деятельности сюрвейеров, возможных сфер занятости и методов организации работы занимаются как иностранные, так и украинские ученые. Ocновные вопросы независимого инспектирования в своих работах рассматривали такие ученные как Дж. Гай, Бр. Лоуэр-Хилл, Капитан С.Б. Томпсон, В.И. Снопков, А.Б. Ляшенко и многие другие. Однако, изучая весь широкий спектр предоставляемых инспекционных услуг, недостаточно внимания было уделено узко специфическим направлениям деятельности сюрвейеров.

Целью данной статьи является исследование спектра независимых инспекционных услуг на основе практики их предоставления при организации контейнерных перевозок в условиях специфических требований китайского рынка к произведенному в Украине шроту подсолнечному. 
ВІСНИК

ОДЕСЬКОГО НАЦІОНАЛЬНОГО

МОРСЬКОГО УНІВЕРСИТЕТУ № 2 (59), 2019
HERALD

OF THE ODESSA NATIONAL

MARITIME UNIVERSITY № 2 (59), 2019

Основной материал статьи. Для китайских потребителей шрот подсолнечный является продуктом довольно новым и используется в основном в составе комбикормов как источник кормового и пищевого белка, при условии отсутствия в нем ГМО. Преимущественной характеристикой шрота подсолнечного является отсутствие антипитательных факторов, которые присутствуют в соевом, рапсовом и хлопковом шроте и устанавливают ограничения по их использованию в кормах [2]. Так же его важным преимуществом относительно соевого или рапсового шрота является относительно низкая цена.

Китайский рынок достаточно сложный, но является многообещающим для украинского производства. В соответствии с официальными требованиями, шрот подсолнечный экспортируемый в КНР, должен соответствовать стандартам Китая по безопасности и гигиене кормов, а именно не должен содержать карантинных организмов, находящихся под контролем в Китае, а также других живых вредителей и семена растений, навоз или трупы животных, перья птицы, почву и генетически модифицированные организмы.

С момента подписания протокола, право на экспорт шрота подсолнечного в КНР получили 24 украинских предприятия [3].

На сегодняшний день можно выделить два основных способа доставки шрота подсолнечного в КНР, которые используют украинские продавцы - навалом или в контейнерах.

При перевозках шрота подсолнечного навалом перед украинским продавцом возникают определенные сложности. Для выгодной ставки фрахта, при условии максимального использования грузовместимости или грузоподъемности судна, отправителю необходимо ставить под погрузку суда размером 45-60 тысяч тонн, что, в свою очередь, является сложно реализуемым для украинских портов именно для данного конкретного вида груза. К тому же, один производитель не может накопить достаточную партию груза, соответственно возникает потребность в комбинированных отгрузках с несколькими грузоотправителями.

В свою очередь, контейнерные перевозки имеют преимущество в виду следующих факторов:

- широкий выбор линейных перевозчиков и, соответственно, конкурентоспособные ставки на перевозку что позволяет произвести рациональный выбор перевозчика;

- регулярное движение, что в свою очередь позволяет экспортерам подготовить груз точно к постановке судна и снизить расходы на складирование;

- для стоимости перевозки контейнерами расстояние не имеет значения. Более важным является объем обратного потока. И в связи с тем, что КНР экспортирует много продукции в Украину, то и экспортный фрахт предлагается контейнерными линиями по разумным ценам. 
ВІСНИК

ОДЕСЬКОГО НАЦІОНАЛЬНОГО

МОРСЬКОГО УНІВЕРСИТЕТУ № 2 (59), 2019
HERALD

OF THE ODESSA NATIONAL

MARITIME UNIVERSITY № 2 (59), 2019

На сегодняшний день, экспортные отгрузки шрота подсолнечного в КНР осложняются и рядом других требований, кроме верного выбора способа перевозки. Китайская сторона требует не только специальную аккредитацию производственных комплексов, но и проведение дополнительных, независимых анализов качественных показателей груза, а также покупателем запрашиваются дополнительные пакеты сопроводительных документов.

Все условия сделок между украинскими производителями и китайскими покупателями прописываются в договорах купли-продажи регулируемыми Ассоциацией Торговли Зерном и Кормами GAFTA.

Следует заметить, что срок годности шрота подсолнечного, соответственно технической документации, составляет от 3 до 6 месяцев, определенное время занимает и накопление партии груза, а транспортировка товара из Украины в Китай, обычно составляет около 1 месяца. В течение этого времени шрот подсолнечный, при игнорировании элементарных правил при его погрузке в контейнер, может сильно повреждаться.

Именно вышеперечисленные факторы определяют целесообразность обращения сторон данного процесса к услугам независимого сюрвейера. В соответствии с определением, сюрвейер - независимый инспектор, предоставляющий услуги по независимому и беспристрастному количественному и качественному инспектированию различных товаров в соответствии с современными международными требованиями. В качестве сюрвейеров выступают обычно профессионалы высокой квалификации, предоставляющие инспекционные услуги на всех этапах грузоперевозок: от пункта производства до страны назначения, а также производящие лабораторные исследования продукции на соответствие контрактным спецификациям или международно-признанным стандартам.

В Украине деятельность сюрвейерских организаций не лицензируется, но в условиях требований современного рынка шрота подсолнечника, инспектор должен представлять сюрвейерскую компанию, имеющую аккредитации в таких международных ассоциациях как GAFTA и FOSFA, а также отвечать требованиям системы менеджмента качества ISO 9001. Обязательным условием является и аккредитация лаборатории сюрвейерской компании, которая подтверждает квалификацию персонала, дает уверенность в результатах полученных независимой лабораторией, а также в правильности их интерпретации.

Таким образом, при соответствии вышеизложенному, независимый инспектор может предоставлять следующие услуги.

1. Определение пригодности и соответствия поданных под погрузку контейнеров для перевозки шрота подсолнечного, которые подает транспортно-экспедиторская компания на склад. 
ВІСНИК

ОДЕСЬКОГО НАЦІОНАЛЬНОГО

МОРСЬКОГО УНІВЕРСИТЕТУ № 2 (59), 2019
HERALD

OF THE ODESSA NATIONAL

MARITIME UNIVERSITY № 2 (59), 2019

До начала погрузки независимый инспектор производит тщательный визуальный осмотр каждого контейнера на предмет его соответствия требованиям для перевозки шрота подсолнечного. Контейнер должен быть чистым, сухим, обеспечивающим герметичность, без постороннего запаха, следов плесени или ржавчины, а также без остатков предыдущего груза. Если контейнер не соответствует, хотя бы одному из вышеуказанных условий, сюрвейер имеет право не допустить данный контейнер под погрузку. Следующим этапом подготовки контейнера к погрузке шрота подсолнечного, выполнение которого фиксирует независимый инспектор, чаще всего является обшивка боковых стен и пола контейнера листами картона. Так как в процессе транспортировки шрота подсолнечного в контейнерах, из-за разницы температур, с высокой вероятностью, может произойти заплесневения груза, еще одной обязанностью сюрвейера является контроль использования силикагеля - абсорбента для впитывания излишней влаги. Последним пунктом подготовки контейнера к погрузке является оборудование его щитом для предотвращения просыпания груза, обычно из ориентировано-стружечной плиты или деревянным. Сюрвейер должен убедиться в том, что установленный щит соответствует требованиям китайской стороны, а именно промаркирован знаком «IPPC» - что означает фитосанитарную обработку щита по стандарту ISPM 15.

2. Контроль грузовых операций, а именно, непрерывное наблюдение за погрузочными операциями и внешним состоянием груза.

Инспекция должна осуществляться непрерывно в течение всей погрузки, с точки, максимально приближенной к месту погрузки с соблюдением всех необходимых мер безопасности. Чаще всего процесс погрузки шрота подсолнечного происходит по схеме склад - пневмопогрузчик/ ленточный конвейер - контейнер. При этом груз неравномерно распределяется по контейнеру, вследствие чего может потребоваться также и ручной труд работников склада для равномерного распределения веса на оси контейнера.

В ходе погрузки инспектор должен обращать внимание на цвет груза (не является ли груз смесью двух различных грузов), размер гранул, сухость или влажность на ощупь, наличие или отсутствие посторонних включений, загрязнений или повреждений груза. Обо всех особенностях ведения погрузочных операций, а также о любых несоответствиях независимый инспектор обязан должным образом и своевременно уведомлять заказчика услуг [4]. Следует заметить, что для своевременной передачи информации и фиксирования возникающих дефектов сюрвейер должен быть оснащен фотоаппаратом либо видеокамерой. Точное время начала и окончания погрузки должны быть зафиксированы.

3. Контроль процесса взвешивания.

Перед использованием весов для определения массы погруженного в контейнер груза, сюрвейеру необходимо проверить документы о 
последней калибровке весов. Весы должны быть расположены на территории склада, где происходит погрузка. Инспектор должен гарантировать, что контейнер был взвешен порожнем, а после завершения погрузки, каждый контейнер вернулся обратно на весы для взвешивания в груженом состоянии. Информация о весе контейнера порожнем, массе брутто и нетто должна быть точно зафиксирована сюрвейером.

4. Отбор проб в соответствии с международными правилами отбора проб GAFTA № 124 [5].

Отбор проб должен производиться регулярно и систематически, через определенные промежутки времени одновременно с погрузкой, путем поперечного пересечения вертикального движущегося потока груза. Такие пробы должны отбираться ручным совком или щупом и носят название точечных либо одиночных. Вес каждой одиночной пробы не должен превышать 1 кг. В зависимости от размера партии шрота подсолнечного, который отгружается в контейнер, зависит и количество одиночных проб, которые должны быть отобраны (таблица).

Таблийа

Правила отбора одиночныхх проб

\begin{tabular}{|l|c|c|c|c|}
\hline Размер партии груза, т & $0-5000$ & $50001-10000$ & $10001-25000$ & $>25000$ \\
\hline Размер лота, т & 500 & 1000 & 2500 & 5000 \\
\hline Количество одиночных проб, ед. & мин. 20 & мин. 30 & мин. 40 & мин. 50 \\
\hline
\end{tabular}

Каждая партия делится на лоты, для каждого лота одиночные пробы отбираются, а затем хранятся, отдельно.

Каждая проба должна быть соответствующим образом упакована и опломбирована - иметь бирку с указанием номера контейнера, датой и местом отбора, общим количеством груза в партии, номером пломбы и другой необходимой информацией.

5. Замеры температуры груза и окружающей среды.

Шрот подсолнечный является гигроскопичным продуктом - впитает в себя влагу из окружающей среды. Поэтому, в замкнутом, невентилируемом пространстве контейнера возможно появление плесени. Во избежание этого, ДСТУ 4638:2006 [6] регламентирует среднюю разность между температурой груза во время погрузки и температурой окружающей среды не более $5{ }^{\circ} \mathrm{C}$.

6. Мониторинг процесса фумигации.

Независимый инспектор должен убедиться не только в факте проведения фумигации, а также проверить препарат, который используется в данном процессе и его дозировку.

7. Контроль соответствия всех заявленных требований для определённой партии погруженного груза.

Сюрвейер обязан гарантировать точное соблюдение контрактных требований всеми сторонами погрузочного процесса. 
8. Опломбирование дверей контейнера по окончанию погрузки.

По требованию заказчика услуг, независимый сюрвейер проводит опломбирование дверей контейнера, а также контролирует и фиксирует факт пломбировки контейнеров линейными пломбами.

9. Химические анализы на соответствие качества погруженного груза заявленным спецификациям.

Независимая лаборатория выполняет анализы, используя методы GAFTA, ISO, ДСТУ, ГОСТ строго соответственно спецификации, которую предоставляет заказчик услуг. Кроме органолептического определения независимой лабораторией натуральности цвета, свежести запаха и проведения основных химических анализов шрота подсолнечного на такие показатели как влажность, протеин, клетчатка и масличность, китайская сторона запрашивает обязательное проведение дополнительных анализов. К ним можно отнести анализы на отсутствие в грузе генномодифицированных организмов, радионуклидов, микробиологических показателей как, к примеру, патогенные микроорганизмы - сальмонелла и стафилококки, микотоксинов, тяжелых металлов, пестицидов, нитратов, нитритов, примесей и других видов химических испытаний.

10. Издание сертификатов соответственно выполненным инспекционным работам.

По факту окончания погрузки инспектор издает «Отчет о погрузке» с указанием зафиксированной на протяжении всей работы информации. На базе данного отчета линейный перевозчик издает коносамент. Финальной стадией работы независимого сюрвейера является издание сертификатов согласно контракту.

Среди базовых сертификатов, которые сюрвейер издает на официальном бланке и заверяет своей подписью и мокрой печатью можно выделить сертификат чистоты контейнеров, сертификат веса, упаковочный лист и сертификаты качества. Во всех сертификатах обязательно указывается порт погрузки и порт выгрузки, наименование товара, общий вес партии груза и даты, когда проводилась инспекция. В соответствии со специфическими требованиями контракта относительно проводимых анализов груза, сюрвейером могут издаваться дополнительные химические и гигиенические сертификаты, а также сертификаты температурных режимов, сертификаты упаковочного материала и другие.

Также, следует отметить, что сюрвейерские сертификаты могут выступать как обязательные и требуемые документы при документарных расчетах между продавцом и покупателем, а именно являться гарантией как для экспортера, так и для импортера в том, что вторая сторона выполнит обязательства по контракту должным образом. В таком случае при издании сертификатов сюрвейеру необходимо строго следовать требованиям аккредитива. 
Вывод. Таким образом, спектр независимых инспекционных услуг, предоставляемых в процессе организации контейнерных перевозок шрота подсолнечного, в условиях специфических требований китайского рынка, может варьироваться. Сюрвейер, являясь обязательным участником транспортного процесса, может выступать в качестве независимого наблюдателя, подтверждающего факт выполнения работ, а также как контролирующий и независимый сертифицирующий орган, гарантирующий соответствие фактов заявленным контрактным требованиям.

\section{СПИСОК ЛІТЕРАТУРИ}

1. Потенциал импорта Китаем подсолнечного шрота может достигнуть 1 млн. тонн - мнения участников рынка (АПКИнформ: ИТОГИ № 8 (50)) [Електронний ресурс] // Информационно-аналитическое агентство «АПК-Информ». 2018. Режим доступу до ресурсу: https://www.apk-inform.com/ru/ exclusive/opinion/1099992

2. Евтушенко С.Л. Влияние качественных показателей сырья и технологического прочесса на содержание протеина в семенах подсолнечника и продуктах его переработки [Електронний ресурс] / С.Л. Евтушенко. 2008. Режим доступу до pecypcy: http://repository.kpi.kharkov.ua/bitstream/KhPI-Press/ 32485/1/vestnik_KhPI_2008_3_Evtushenko_Vliyanie.pdf

3. Украинский подсолнечный шрот благодаря Госпродпотребслужбе вышел на рынок Китая [Електронний ресурс] // Украӥнська Зернова Асоціачія. 2018. Режим доступу до pecypcy: http://uga.ua/meanings/ukrainskij-podsolnechnyj-shrotblagodarya-gosprodpotrebsluzhbe-vyshel-na-rynok-kitaya

4. Учебные материаль для курсов повышения квалификации грузовых сюрвейеров / А.Б. Ляменко, А.А. Гриченко, А.А. Мошнянский та ін. Одесса: Одесский государственный морской университет, 2001.

5. THE GRAIN AND FEED TRADE ASSOCIATION. Sampling Rules № 124 [Електронний ресурс] / THE GRAIN AND FEED TRADE ASSOCIATION // Printedin England and issuedby GAFTA. 2012. Режим достуny до ресурсу: https://www.gafta.com/write/ Media Uploads/Contracts/2012/124.pdf

6. ШРОТ ПОДСОЛНЕЧНЫЙ. ДСТУ 4638:2006. Технические условия [Електронний ресурс] // ГОСУДАРСТВЕННЫЙ СТАНДАРТ УКРАИНЫ. 2007. Режим доступу до ресурсу: https://agrotender.com.ua/files/Baza\%20znaniy/GOSTi/Shrot_Pod solnechniy_DSTY_4638.pdf 


\section{REFERENCES}

1. Information and analytical agency «APK-Inform» (2018) Potentsial importa Kitaem podsolnechnogo shrota mozhet dostignut' 1 mln. tonn - mneniya uchastnikov rynka (APK-Inform: ITOGI № 8 (50)) [The potential of China's sunflowerseed meal import can reach 1 million tons - the opinions of market participants APK-Inform: RESULTS № 8 (50))]. Information and analytical agency "APK-Inform». Available at: https://www.apkinform.com/ru/ exclusive/opinion/1099992 (accessed 10 December 2018).

2. Evtushenko S.L. (2008) Vliyanie kachestvennykh pokazateley syr'ya $i$ tekhnologicheskogo protsessa na soderzhanie proteina $v$ semenakh podsolnechnika $i$ produktakh ego pererabotki [The influence of quality indicators of raw materials and the technological process on the protein content in sunflower seeds and its processed products]. Vestnik Natsional'nogo tekhnicheskogo universiteta "KhPI": sbornik nauchnykh trudov Tematicheskiy vypusk: Novye resheniya v sovremennykh tekhnologiyakh, № 3, pp. 89-97.

3. Ukrainian Grain-growing Association (2018) Ukrainskiy podsolnechnyy shrot blagodarya Gosprodpotrebsluzhbe vyshel na rynok Kitaya [Ukrainian sunflowerseed meal due to Government food consumer service went out to the market of China], Ukrainian Grain-growing Association. Available at: http://uga. ual meanings/ukrainskij-podsolnechnyj-shrot-blagodarya-gosprodpotrebsluzhbe-vyshel-na-rynok-kitaya/ (accessed 15 March 2019).

4. Lyashenko A.B., Gritsenko A.A., Moshnyanskiy A.A. (2001) Uchebnye materialy dlya kursov povysheniya kvalifikatsii gruzovykh syurveyerov [Educational materials for training courses of surveyors]. Odessa: Odessa State Maritime University.

5. Printedin England and issuedby GAFTA (2012) The grain and feed trade association. Sampling Rules No.124. Available at: https://www.gafta.com/write/MediaUploads/Contracts/2012/124.p df (accessed 04 April 2019).

6. Derzhavnyj komitet Ukrajiny z pytanj tekhnichnogho reghuljuvannja ta spozhyvchoji polityky (2006) DSTU 4638:2006. Shrot sonjashnykovyj. Tekhnichni umovy [DSTU 4638:2006. Meal sunflower. Technical conditions]. Kyiv: Derzhavnyj komitet Ukrajiny z pytanj tekhnichnogho reghuljuvannja ta spozhyvchoji polityky

Стаття надійшла до редакиії 20.10.2019 


\begin{tabular}{c|c} 
ВІСНИК & HERALD \\
ОДЕСЬКОГО НАЦІОНАЛЬНОГО & OF THE ODESSA NATIONAL \\
МОРСЬКОГО УНІВЕРСИТЕТУ & MARITIME UNIVERSITY \\
№ $2(59), 2019$ & № $2(59), 2019$ \\
\hline \hline
\end{tabular}

\section{Рецензенти:}

доктор економічних наук, професор, професор кафедри «Експлуатація флоту i технологія морських перевезень» Одеського національного морського університету С.П. Онищенко

доктор економічних наук, професор, головний науковий співробітник відділу макроекономіки та державного управління Причорноморського науково-дослідного інституту економіки та інновацій С.М. Мінакова 